\title{
THE RESPONSE OF THE EWE TO PREGNANT MARE SERUM AND TO HORSE ANTERIOR PITUITARY EXTRACT
}

\author{
J. N. SHELTON AND N. W. MOORE \\ Department of Animal Husbandry, University of Sydney, \\ and McCaughey Memorial Institute, Jerilderie, N.S.W., Australia
}

(Received 14th April 1967)

\begin{abstract}
Summary. When compared in ewes at three dose-rates horse anterior pituitary extract (HAP) produced a different ovarian response to that of pregnant mare serum gonadotrophin (PMSG). Although there was no difference in number of ovulations, there was a greater number of persistent follicles after PMSG. Because persistent follicles are associated with a decreased percentage of fertilized ova, HAP is more suited than PMSG to the production of large numbers of fertilized sheep ova.
\end{abstract}

In the late spring (November) a factorial experiment of two-fold purpose was conducted first, to test a continuous progesterone treatment technique and second, to compare pregnant mare serum (PMSG) and an equine anterior pituitary extract (HAP) for the induction of oestrus and ovulation in the anoestrous Border Leicester $\times$ Merino ewe.

Progesterone was administered for 12 days either by daily intramuscular injection in peanut oil $(10 \mathrm{mg} /$ day) or by subscutaneous $2-\mathrm{mm}$ bore polythene catheter inserted into the side of the animal and fed by gravity from a polythene bottle attached to the back and containing $30 \mathrm{ml}$ of a propylene glycol solution of progesterone $(15 \mathrm{mg} / \mathrm{ml})$. A third group of ewes received no progesterone (Table 1). The PMSG was in the form of whole serum which had been stored at $-20^{\circ} \mathrm{C}$ since collection and the HAP was prepared by the method described by Moore \& Shelton (1962). PMSG was administered subcutaneously as a single injection of 3,6 or $12 \mathrm{ml}$ on the last day of progesterone treatment. The HAP was administered at total doses 30,60 or $120 \mathrm{mg}$ divided into five equal subcutaneous injections given at 12 -hr intervals beginning $12 \mathrm{hr}$ before the end of progesterone treatment. These doses were selected after previous pilot tests, and Table 2 indicates that the lowest doses gave similar ovarian responses. Ewes not given progesterone were treated with PMSG or HAP at the same time as those given progesterone.

The ewes in oestrus within 7 days after termination of progesterone treatment were recorded, and all ewes were subjected to laparotomy on the 7th day, when the numbers of recent ovulations and unruptured follicles greater than $5 \mathrm{~mm}$ in diameter were recorded. 
The main treatment effects are presented in Table 1 . The response following continuous progesterone treatment was poor, but the fact that some ewes exhibited oestrus (six out of eighteen) indicated that a small, though suboptimal, amount of progesterone had been absorbed. There were no treatment

TABLE 1

THE OESTROUS AND OVARIAN RESPONSES OF EWES TO PMSG AND HAP AFTER PROGESTERONE TREATMENT

\begin{tabular}{|c|c|c|c|c|c|c|}
\hline & \multicolumn{3}{|c|}{ No. of ewes } & \multicolumn{3}{|c|}{ Ovarian response } \\
\hline & Treated & $\begin{array}{c}\text { Oestrous } \\
\text { post- } \\
\text { treatment }\end{array}$ & $\begin{array}{c}\text { Ovulated } \\
\text { post- } \\
\text { treatment }\end{array}$ & $\begin{array}{l}\text { Total } \\
\text { (ovulations } \\
+ \text { persistent } \\
\text { follicles) } \\
\quad(a)\end{array}$ & $\begin{array}{l}\text { Ovulations } \\
\text { (b) }\end{array}$ & $\begin{array}{l}\text { Ovulations } \\
\text { as propor- } \\
\text { tion of total } \\
\text { response } \\
(b / a)\end{array}$ \\
\hline $\begin{array}{l}\text { Progesterone treatment } \\
\text { Daily injection } \\
\text { Continuous injection } \\
\text { Nil } \\
P \text { linear } \\
\quad \text { quadratic }\end{array}$ & $\begin{array}{l}18 \\
18 \\
18\end{array}$ & $\begin{array}{c}14 \\
6 \\
0 \\
<0.001 \\
\text { N.S. }\end{array}$ & $\begin{array}{l}18 \\
18 \\
17 \\
\text { N.S. } \\
\text { N.S. }\end{array}$ & $\begin{array}{l}141 \\
124 \\
100 \\
\text { N.S. } \\
\text { N.S. }\end{array}$ & $\begin{array}{l}91 \\
82 \\
48 \\
<0.05 \\
\text { N.S. }\end{array}$ & $\begin{array}{l}91 / 141 \\
82 / 124 \\
48 / 100 \\
\text { N.S. } \\
\text { N.S. }\end{array}$ \\
\hline $\begin{array}{l}\text { Gonadotrophin } \\
\text { PMSG } \\
\text { HAP } \\
P\end{array}$ & $\begin{array}{l}27 \\
27\end{array}$ & $\begin{array}{c}10 \\
10 \\
\text { N.S. }\end{array}$ & $\begin{array}{c}26 \\
27 \\
\text { N.S. }\end{array}$ & $\begin{array}{c}221 \\
144 \\
<0.01\end{array}$ & $\begin{array}{l}106 \\
115 \\
\text { N.S. }\end{array}$ & $\begin{array}{c}106 / 221 \\
115 / 144 \\
<0.01\end{array}$ \\
\hline $\begin{array}{l}\text { Dose gonadotrophin } \\
-1 \\
0 \\
+1 \\
P \text { linear } \\
\quad \text { quadratic }\end{array}$ & $\begin{array}{l}18 \\
18 \\
18\end{array}$ & $\begin{array}{r}7 \\
7 \\
6 \\
\text { N.S. } \\
\text { N.S. }\end{array}$ & $\begin{array}{l}18 \\
17 \\
18 \\
\text { N.S. } \\
\text { N.S. }\end{array}$ & $\begin{array}{c}53 \\
128 \\
184 \\
<0 \cdot 001 \\
\text { N.S. }\end{array}$ & $\begin{array}{l}49 \\
83 \\
89 \\
\simeq 0.05 \\
\text { N.S. }\end{array}$ & $\begin{array}{l}49 / 53 \\
83 / 128 \\
89 / 184 \\
<0.01 \\
\text { N.S. }\end{array}$ \\
\hline
\end{tabular}

There were no significant interactions.

effects on the number of ewes that ovulated. However, there was a marked difference in favour of PMSG in the total ovarian response $(P<0.01)$ but, because of a large difference in the proportion of follicles that ovulated $(P<0.01)$, there

TABLE 2

OVARIAN RESPONSES OF EWES TO THREE DOSES OF PMSG AND HAP

\begin{tabular}{c|c|c}
\hline Gonadotrophin & Dose & $\begin{array}{c}\text { Ovulations as proportion } \\
\text { of total response }\end{array}$ \\
\hline PMSG & $3 \mathrm{ml}$ & $26 / 29$ \\
& $6 \mathrm{ml}$ & $43 / 74$ \\
HAP & $12 \mathrm{ml}$ & $37 / 118$ \\
& $30 \mathrm{mg}$ & $23 / 24$ \\
& $60 \mathrm{mg}$ & $40 / 54$ \\
& $120 \mathrm{mg}$ & $52 / 66$ \\
\hline
\end{tabular}

was no difference in the number of ovulations in ewes given PMSG and HAP. Increasing doses of gonadotrophins produced a highly significant linear increase in total response $(P<0.001)$ but only a small increase in the number of ovula- 
tions $(P \doteq 0.05)$. This can be attributed to a linear decrease $(P<0.01)$ in the proportion of follicles that ovulated. Regardless of the gonadotrophin and dose administered the ovarian response was generally poor. This was probably due to the anoestrous state of the ewes.

The dose-response relationships for PMSG and HAP were quite different (Table 2). In ewes that received the lowest doses of PMSG and HAP there was no difference in the proportion of follicles that ovulated $\left(\chi^{2}=0.11 ;\right.$ d.f. $=1 ;$ N.S.), whereas with the highest doses there was a highly significant difference in the proportion of follicles that ovulated $\left(\chi^{2}=36.35\right.$; d.f. $\left.=1 ; P<0.001\right)$.

PMSG has been widely used to obtain multiple foetation in ewes (Robinson, 1951; Wallace, 1954) and to induce multiple ovulation for ovum transfer (Hunter, Adams \& Rowson, 1955; Averill \& Rowson, 1958). Anterior pituitary extracts have also been used for these purposes (Hammond, Hammond \& Parkes, 1942; Casida, Warwick \& Meyer, 1944) and Moore \& Shelton (1964) suggested that it might be more reliable than PMSG. Van Rensburg (1964) compared PMSG and HAP at one dose-rate. He obtained a greater yield of ova from ewes treated with HAP and observed that the percentage of fertilized ova decreased with increasing number of persistent follicles. Moore \& Shelton (unpublished data) made a similar observation.

The results presented here show that HAP produces a smaller number of persistent follicles than PMSG particularly at high doses and thus is more suited to the production of large numbers of fertilized sheep ova.

\section{REFERENCES}

Avericl, R. W. L. \& Rowson, L. E. A. (1958) Ovum transfer in the sheep. F. Endocr. 16, 326.

CASTDA, L. E., WARWICK, E. J. \& MEYER, R. K. (1944) Survival of multiple pregnancies induced in the ewe following treatment with pituitary gonadotrophins. F. Anim. Sci. 3, 22.

Hammond J., JR, Hammond, J. \& Parkes, A. S. (1942) Hormonal augmentation of fertility in sheep. I. Induction of ovulation, superovulation and heat in sheep. F. agric. Sci. 32, 308.

Hunter, G. L., Adams, C. E. \& Rowson, L. E. A. (1955) Inter-breed ovum transfer in sheep. F. agric. Sci. 46, 143.

Moore, N. W. \& Shelton, J. N. (1962) Oestrous and ovarian response of the ewe to a horse anterior pituitary extract. Nature, Lond. 194, 1283.

Moore, N. W. \& Shelton, J. N. (1964) Response of the ewe to a horse anterior pituitary extract. 7. Reprod. Fert. 7, 79.

Rosinson, T. J. (1951) The control of fertility in sheep. Part II. The augmentation of fertility by gonadotrophin treatment of the ewe in the normal breeding season. $\mathcal{F}$. agric. Sci. 41, 6.

VAN RENSBURG, S. J. (1964) Ovum production: action of various gonadotrophins in sheep and goats. Onderstepoort 7. vet. Res. 31, 97.

Wallace, L. R. (1954) Studies in the augmentation of fertility of Romney ewes with pregnant mare serum. 7. agric. Sci. 45, 60 . 